\title{
INVESTIGATION OF ENVIRONMENTAL DAMAGES CAUSED BY EXCAVATED MATERIALS AT FOREST ROAD CONSTRUCTION IN THE MEDITERRANEAN REGION OF TURKEY
}

\author{
SENTURK, N. ${ }^{1 *}-$ OZTURK, T. ${ }^{1}-$ INAN, M. $^{2}-$ BILICI, E. ${ }^{3}$ \\ ${ }^{I}$ Department of Forest Construction and Transportation, Faculty of Forestry, Istanbul \\ University-Cerrahpasa, 34473 Bahcekoy, Istanbul, Turkey \\ ${ }^{2}$ Department of Surveying and Cadastre, Faculty of Forestry, Istanbul University-Cerrahpasa \\ 34473 Bahcekoy, Istanbul, Turkey \\ ${ }^{3}$ Vocational School, Giresun University, Dereli, Giresun, Turkey \\ *Corresponding author \\ e-mail:nsenturk@istanbul.edu.tr \\ (Received $5^{\text {th }}$ Apr 2018; accepted $13^{\text {th }}$ Jun 2018)
}

\begin{abstract}
Forest road constructions have been investigated in terms of damage to trees below road construction areas and in stream beds. In this study, constructing a road using a bulldozer and environmental damages caused by this technique were investigated in the forested regions of Antalya in Turkey. Decision variables were collected from 52 cross sections in a road section that was selected as a sample. In these cross sectional areas, the number of damaged and undamaged trees was determined in each cross section. Another damage type, the damage in stream beds was investigated based on deposits of excavated materials dumped during the forest road construction operation. The slope in this research area varied between $25-80 \%$. Moreover, the maximum and the minimum length of fill areas in different cross sections was found to be approximately between 2 and $16 \mathrm{~m}$. In this study, the rate of bending damage to trees below the road construction areas was $26.3 \%$, and the rate of wounding damage was $6.1 \%$. The number of damaged trees in various gradient was also determined in the study area. Along the chosen road section, debris were found to cover the stream bed in some areas. The wounding of tree barks was serious in this forest region although there was also significant damage caused by bark beetles.
\end{abstract}

Keywords: road, tree damages, cross section, stream bed

\section{Introduction}

Forest roads are necessary to provide access to forests for general management, maintenance, timber extraction, recreation (Ryan et al., 2004), regeneration, production (Demir and Hasdemir, 2005), and fire and pest control (Tehrani et al., 2015). Forest roads are associated with economic growth and national wealth. However, they have various direct and indirect effects on their adjacent environment (Tehrani et al., 2015). Construction of a forest road network is considered as the key element for a successful forest management (Krc and Begus, 2013). Planning a forest road network depends on social requirements since such roads provide access to forest villages, rural settlements and recreational areas (Acar and Eker, 2003). When forest roads are routed, construction methods and equipment selection directly affect their economical, functional and ecological efficiency (Ozturk et al., 2010). A proper design and routing of forest roads will reduce the need for major repairs and save on maintenance costs over time (Edwards, 2011).

Forest roads also have major environmental impacts. The environmental impacts of forest road constructions vary according to conditions of a terrain, that is whether it is a 
rocky, loose rock, soil, gentle or steeper terrain, and so forth. In addition, in general, environmental damage may increase depending on situations such as stands (average tree diameters, average tree lengths, stand ages, canopy closures, etc.), choice of machines, tree species, and road construction techniques. Building forest roads involves removal of vegetation and soil, thus favoring run-offs, pollution of streams, and the risk of erosion and mass movement on steeper terrains (Edwards, 2011; Hernandez-Diaz et al., 2015). Moreover, stream beds can fill up with excavated materials, which is very concerning in terms of freshwater ecology, fish health, and rerouted stream beds.

Various types of bulldozers and excavators are generally used in forest road construction operations in Turkey. Bulldozers are commonly preferred on terrains with gentle to moderate hillside slopes and on soil and loose rock grounds. However, in steep and rocky terrain conditions, the efficiency of bulldozers diminishes, and excessive environmental damages may occur because of the difficulty to keep excavated materials alongside the road (Ozturk, et al., 2009).

In this study, a forest road construction was investigated in the southern part of Turkey. The construction was carried out by using a bulldozer. Environmental damages to trees and to the stream bed caused by the forest road construction were investigated. In addition, productivity and cost of the bulldozer were evaluated, and some suggestions were offered.

\section{Materials and methods}

\section{Study area}

The study area is selected from the office zone Gursu Forest Enterprise in Kas Forest Management in Antalya (Fig. 1). In this enterprise, dominant commercial tree species include Pinus brutia, Cedrus libani and Juniperus sp. The elevation ranges from $500 \mathrm{~m}$ to $1200 \mathrm{~m}$ with ground slopes of $25 \%$ to $80 \%$. The study area consists of Type B forest roads with a density of $16 \mathrm{~m} / \mathrm{ha}$. Total length of the sample road examined in this study was about $1575 \mathrm{~m}$ with an average road width of $5 \mathrm{~m}$. The study area is located on the Taurus Mountainous, which is the largest and most important karst region in Turkey. Due to immediate penetration of rainfall and snowmelt into the rock crack system, surface soil formation very slowly occurs along the cracks and statification surfaces of the limestone. In this study area, the road alignment consists of soil and losses rock.

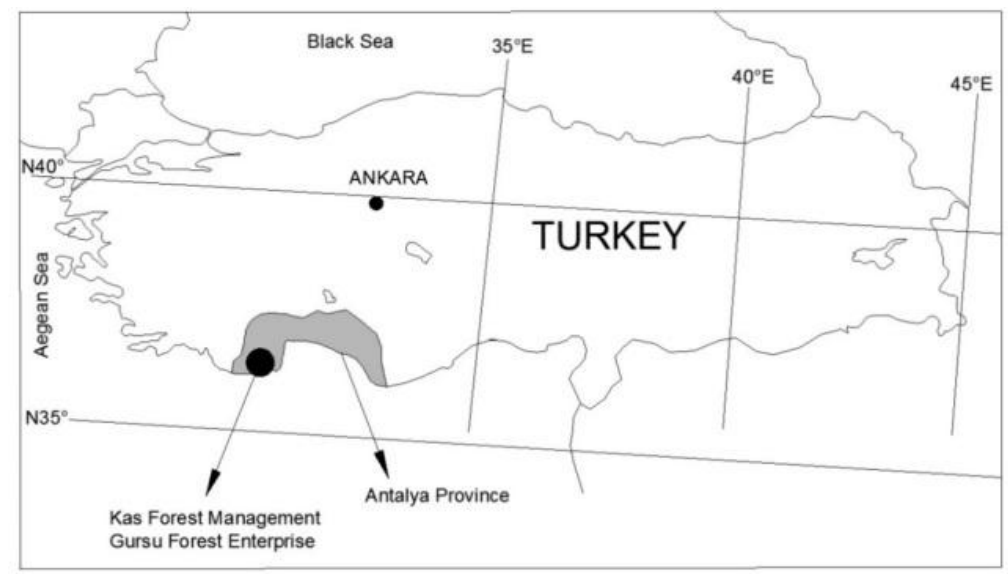

Figure 1. The location of the study area in Antalya region 


\section{The equipment specifications}

Komatsu D85ex type bulldozer was used in forest road construction operations. This bulldozer is a very strong machine and it is suitable for forest road operations on soil and loose rock region. The technical specifications of the bulldozer are shown in Table 1.

Table 1. Technical features of the Komatsu D85ex (Anonymous, 2015)

\begin{tabular}{|c|c|c|}
\hline \multicolumn{2}{|c|}{ Specifications } & Values \\
\hline \multicolumn{2}{|c|}{ Bulldozer weight } & $21220 \mathrm{~kg}$ \\
\hline \multicolumn{2}{|c|}{ Operating weight } & $28100 \mathrm{~kg}$ \\
\hline \multicolumn{2}{|c|}{ Engine model } & SAA6D125E-5 \\
\hline \multicolumn{2}{|c|}{ Engine type } & 4 cycle, water cooled, direct injection \\
\hline \multicolumn{2}{|c|}{ Engine power } & $266 \mathrm{HP}$ \\
\hline \multirow{2}{*}{ Maximum travel speed } & Forward & $10.1 \mathrm{~km} / \mathrm{h}$ \\
\hline & Reverse & $13.0 \mathrm{~km} / \mathrm{h}$ \\
\hline \multicolumn{2}{|c|}{ Blade capacity } & $7.0 \mathrm{~m}^{3}$ \\
\hline \multicolumn{2}{|c|}{ Minimum turning radius } & $1.99 \mathrm{~m}$ \\
\hline \multicolumn{2}{|c|}{ Fuel tank } & 4901 \\
\hline \multicolumn{2}{|c|}{ Bulldozer height } & $3330 \mathrm{~mm}$ \\
\hline \multicolumn{2}{|c|}{ Bulldozer length } & $5795 \mathrm{~mm}$ \\
\hline \multicolumn{2}{|c|}{ Bulldozer width } & $3635 \mathrm{~mm}$ \\
\hline \multicolumn{2}{|c|}{ Ground pressure } & $73.6 \mathrm{kPa}$ \\
\hline
\end{tabular}

\section{Methods}

The area and the trees in it during the forest road construction were measured to determine and investigate the damage caused by the excavated materials. Also, environmental damages to the stream bed caused by the excavated materials were investigated. In this study, primarily, the cross sections were determined along the forest road. Every cross section included different variables. These variables include cut-slope height $(\mathrm{Ch})$, cut-slope width $(\mathrm{Crw})$, road width (Road + Ditch) $(\mathrm{Rw})$, fill-slope width (Frw), fill-slope length $(\mathrm{Fl})$, road construction zone width $(\mathrm{Czw})$, cut slope length $(\mathrm{Cl})$ and ground slope (S) (Fig. 2).

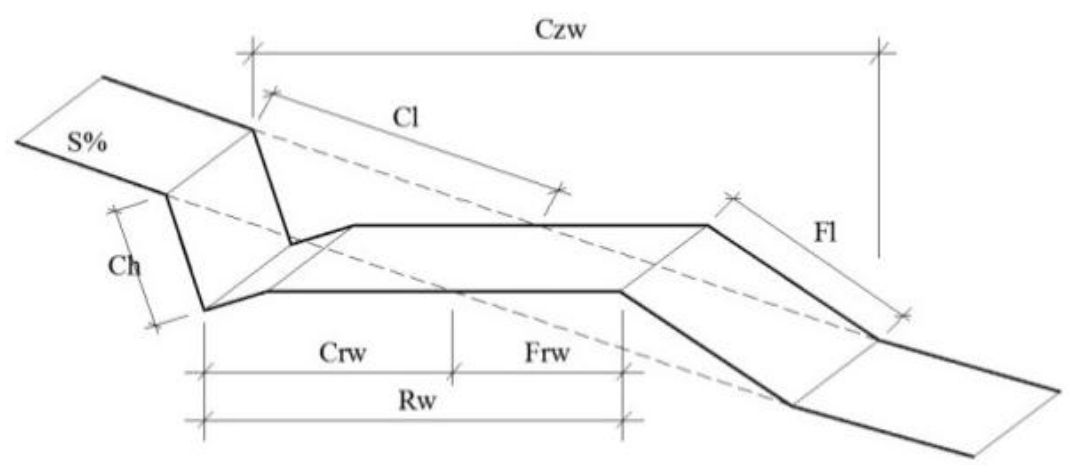

Figure 2. The decision variables measured from each cross section along the forest road 
In this study, surveying instruments such as a steel tape, a measuring batten, clinometers, an altimeter, and a compass were used in the research area. Along the $1,575 \mathrm{~m}$ of road section, decision variables were collected from 52 cross sections, which were $30 \mathrm{~m}$ apart from each other. The number of damaged and undamaged trees were determined in each cross section as a gradient group. The types of damage such as bending of a tree and wounding of tree bark were also observed. Using the data that were collected, distribution of damage types in relation to the construction techniques associated with the bulldozer and the effect of positional values of damaged trees were investigated. The data were entered into a spread-sheet program to compute simple statistics such as arithmetic averages and standard deviations. The average excavation speeds and productivities of the bulldozer were found throughout the forest road operation. Every cross section was shown in percent slopes, differently for cut-slopes and fill-slopes. The shapes of the cross sections were measured, and the difference between the lengths of cut-slopes and fill-slopes was shown.

\section{Results and discussion}

In the first stage of the road construction operation, the trees on the route were cut, and removed. In this route, $386 \mathrm{~m}^{3}$ of logs were extracted from 452 fallen trees that were collected from a single cross section that was selected as a sample along the construction zone. The trees that were cut were mostly Pinus brutia. The results indicated that the total amount of excavated materials along the roadway was $12,195.00 \mathrm{~m}^{3}$, The percentages of soil, loose rock and soft rock of those materials were $59 \%, 36 \%$ and $5 \%$, respectively. The average operation time of the bulldozer was $8 \mathrm{~h}$ per day. The research was conducted in August 2015. The research area is very hot in the summer season, which affected the forest road operation.

\section{Cross sections}

In this study, the data from the cross sections were collected on the sample road. In this region, the types of materials on the ground are soil and loose rock along the forest road construction route. The excavation operation using the bulldozer was easy because the amount of rock on the ground was very small. Table 2 lists the values of the specific variables measured from the cross sections.

Table 2. The values of decision variables measured on the cross sections

\begin{tabular}{c|c|c|c|c|c}
\hline Variables & Symbol & Average & $\begin{array}{c}\text { Standard } \\
\text { deviation }\end{array}$ & Max. values & Min. values \\
\hline Ground slope (\%) & $\mathrm{S}$ & 58.8 & 17.73 & 80 & 25 \\
Cut-slope height (m) & $\mathrm{Ch}$ & 3.51 & 1.43 & 7.8 & 1.7 \\
Cut length on road width (m) & $\mathrm{Crw}$ & 4.31 & 1.10 & 6.5 & 2.9 \\
Fill length on road width (m) & Frw & 2.34 & 1.79 & 8.5 & 0.5 \\
Road width (m) & $\mathrm{Rw}$ & 6.56 & 1.72 & 12.0 & 4.2 \\
Cut-slope length (m) & $\mathrm{Cl}$ & 6.55 & 1.85 & 10.8 & 3.9 \\
Fill-slope length (m) & $\mathrm{Fl}$ & 5.67 & 3.82 & 16.2 & 1.9 \\
Construction zone width (m) & $\mathrm{Czw}$ & 11.32 & 3.40 & 19.5 & 6.9 \\
\hline
\end{tabular}


The average construction zone width was $11.32 \mathrm{~m}$; therefore, the sample road section affected approximately 1.78 ha of the forested area $(11.32 \mathrm{~m} \times 1,575 \mathrm{~m}=$ $17,829 \mathrm{~m}^{2}=1.78 \mathrm{ha}$ ) during the road construction activity.

In this study, the rates of cut-slopes in the forest road were mostly between $3 / 1$ and $5 / 1$ depending on the cut-slope heights and road widths. Excavated materials were scattered down the side of the roadway, and the fill-slope lengths varied between 1.9 and $16.2 \mathrm{~m}$ depending on the fill-slope gradients. The gradient of study area was found to be between 25 and $80 \%$.

\section{Environmental damages on trees and stream bed}

Some of the cross sections did not have any damaged trees, whereas the others had damaged trees (Fig. 3). The damaged trees usually had bending and wounding damages (Figs. 4 and 5). The number and rate of the damaged trees in the study area is shown in Table 3.

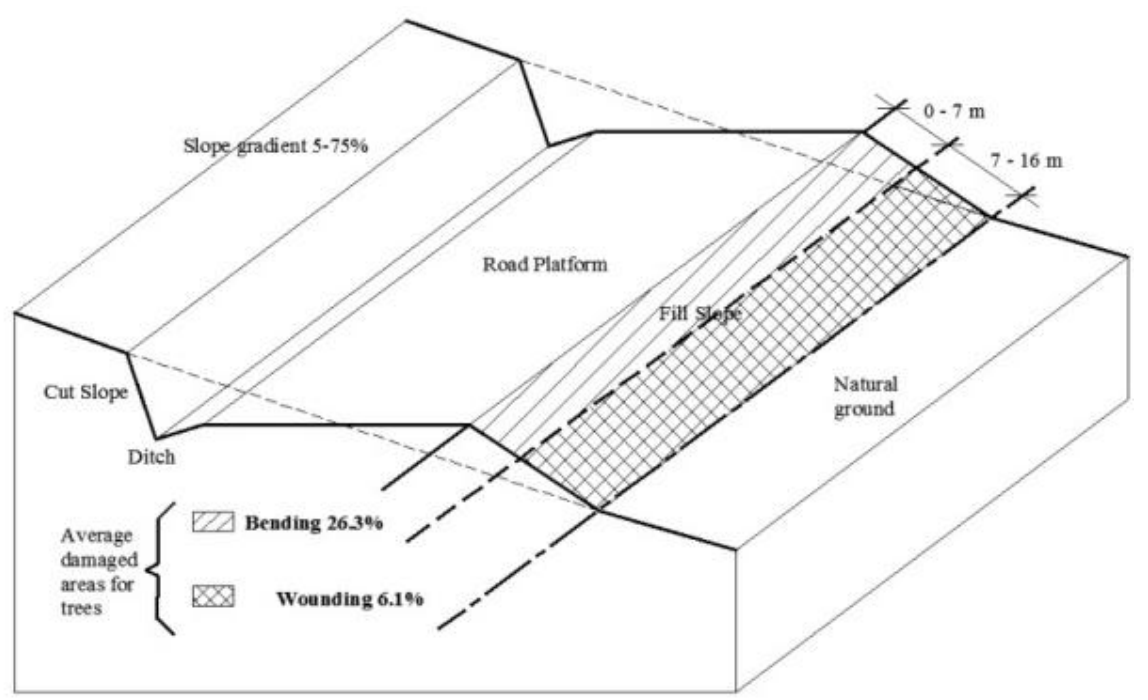

Figure 3. Determination of cross sections along the road alignment

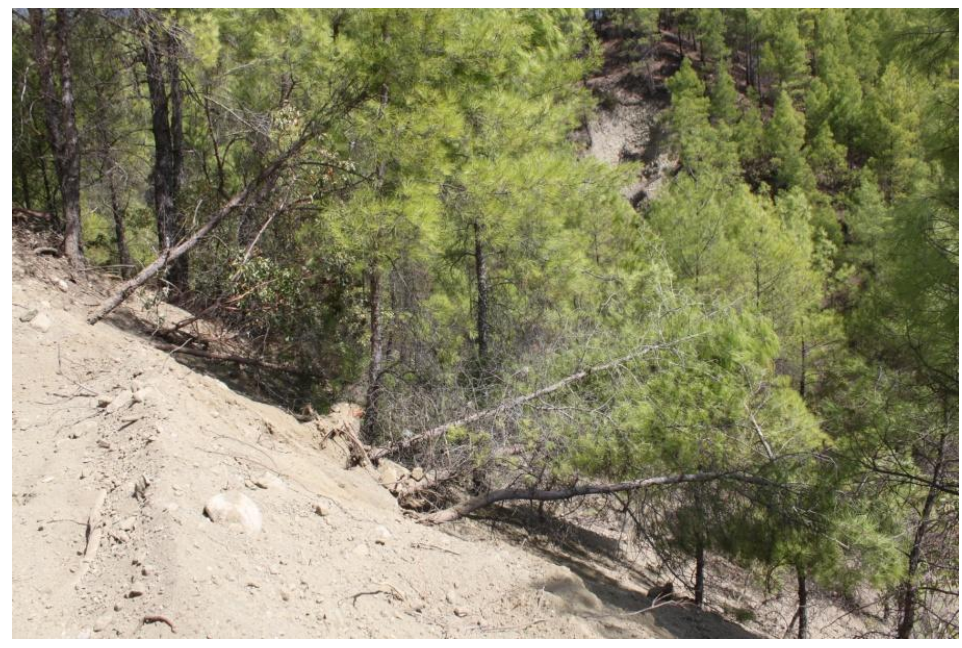

Figure 4. Bending damages of trees 


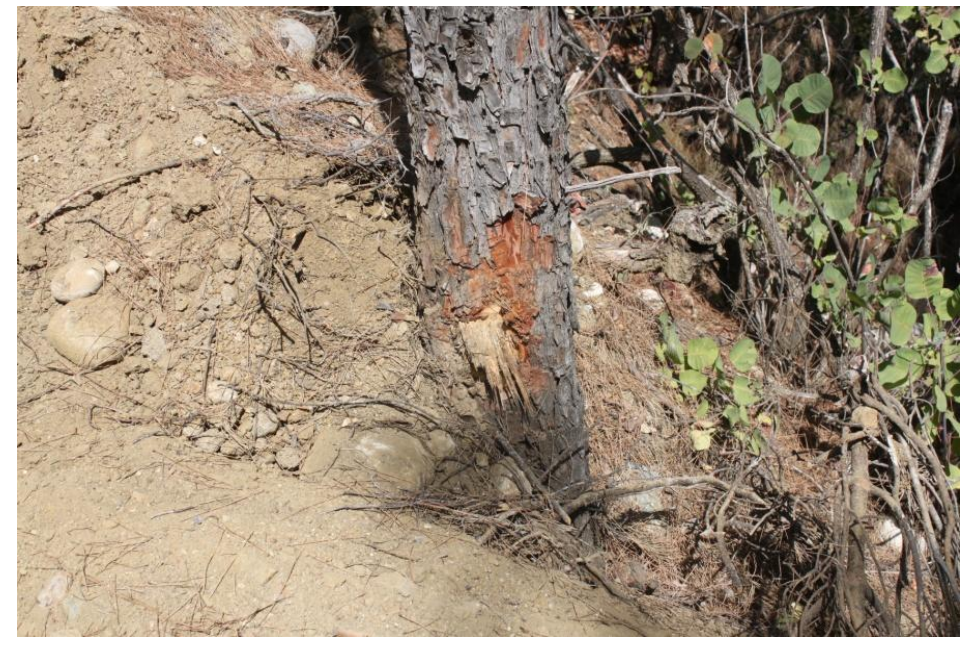

Figure 5. Wounding damages of trees

The wounding of the tree barks is a very serious issue for this forest region. For many years, bark beetles have been devastating this region. The damage caused by bark beetles is denser especially on Pinus brutia. The environmental damage may be increased in these regions due to bark beetles. In addition, direct economic losses are rising due to the timber quality lowered by bark beetles.

Table 3. Number and rate of damaged trees in study areas

\begin{tabular}{c|c|c|c|c|c|c|c|c}
\hline $\begin{array}{c}\text { Cross } \\
\text { section } \\
\text { number }\end{array}$ & $\begin{array}{c}\text { Distance } \\
(\mathbf{m})\end{array}$ & $\begin{array}{c}\text { Average of } \\
\text { grade fill } \\
\text { slope (\%) }\end{array}$ & $\begin{array}{c}\text { Total } \\
\text { number of } \\
\text { trees }\end{array}$ & $\begin{array}{c}\text { Number of } \\
\text { bending } \\
\text { trees }\end{array}$ & $\begin{array}{c}\text { Number of } \\
\text { wounding } \\
\text { trees }\end{array}$ & $\begin{array}{c}\text { Average of } \\
\text { distance } \\
\text { rolling (m) }\end{array}$ & $\begin{array}{c}\text { Bending } \\
\text { percent } \\
(\%)\end{array}$ & $\begin{array}{c}\text { Wounding } \\
\text { percent } \\
(\%)\end{array}$ \\
\hline 1 & 30 & 65 & 24 & 6 & - & 9 & 25 & 0 \\
2 & 30 & 65 & 29 & 9 & 1 & 9.5 & 31 & 3.4 \\
3 & 30 & 75 & 65 & 20 & 3 & 22 & 30.8 & 4.6 \\
4 & 30 & 70 & 22 & 8 & 2 & 9.5 & 36.4 & 9 \\
5 & 30 & 45 & 5 & - & - & 5.5 & 0 & 0 \\
6 & 30 & 72 & 38 & 14 & 5 & 18.5 & 36.8 & 13.2 \\
7 & 30 & 63 & 20 & 4 & 1 & 7.5 & 20 & 5 \\
8 & 30 & 55 & 18 & 8 & 3 & 6 & 44.4 & 16.6 \\
9 & 30 & 40 & 13 & 2 & - & 4.5 & 15.4 & 0 \\
10 & 30 & 58 & 22 & 5 & 2 & 8 & 22.7 & 9 \\
Ort. & 20 & 60.8 & 26 & 8 & 2 & 10 & 26.3 & 6.1 \\
\hline
\end{tabular}

The number of damaged trees in the steep and gentle terrain was found to be greater. In $25-80 \%$ of the sloped areas, there were an average of 8 bent trees and 2 wounded trees. In addition, in the cross sections, the average number of undamaged trees was counted to be 26 . Along the forest road, the average gradient was found to be $61 \%$. The amount of excavated materials along the road alignment and the slope gradient are also important. The length of fill-slopes increases with increasing slope gradients, and consequently, the damage grows. When the sliding and rolling distance of excavated materials increase, the environmental damages to trees and to the river basin are increased. 
All the excavated materials were dumped down the side of the roadway by the bulldozer. As the second type of environmental damage, the stream bed was filled with excavated materials. In this case, the direction of the stream flow was diverted. This change was very serious in terms of freshwater ecology, fish health, and rerouted stream beds (Fig. 6).

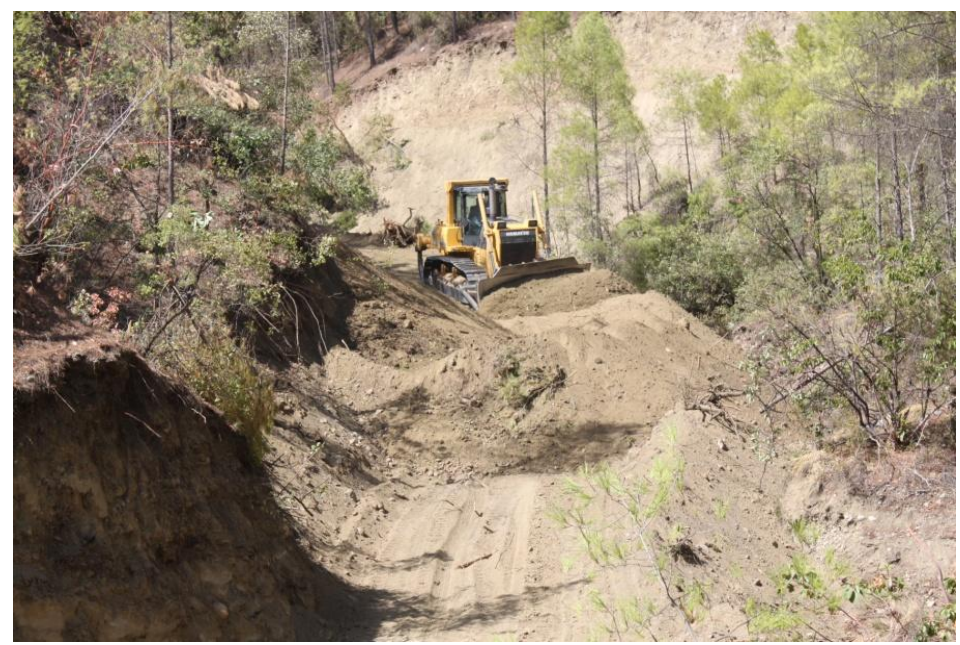

Figure 6. The fill with excavated material of stream bed

Filling stream beds with excavated materials increases the risk of erosion in this area especially in the rainy season. The main reason for dumping excavated materials over the stream bed was the fact that the forest road was very close to the stream. A buffer zone should be allowed between a road and a stream so that the stream can be protected from excavated materials. According to Akgül, the width of a buffer zone should be increased depending on the slope rate. The width of a buffer zone ranges between 25 and $150 \mathrm{~m}$ on productive forest areas (Akgül, 2012). Stream beds are protected from flow of sediments by buffer zones, and thus, the speed of rainwater is reduced in such areas (Wenger, 1999; Wood and Armitage, 1997).

\section{Productivity and cost of bulldozer}

The production rate of the bulldozer is generally computed as the length of constructed road per hour. In this study, the average productivity of the bulldozer in soil, loose rock and soft rock were found to be 221.41, 125.00 and $86.5 \mathrm{~m}^{3} / \mathrm{h}$, respectively (Table 4).

The average slopes of soil, loose rock and soft rock in the study area were 55, 66 and $63 \%$, respectively. The total road construction cost of the Gürsu region was $14,750.00$ US\$, with a unit cost of $9,370.00 \mathrm{US} \$ / \mathrm{km}$. The fuel consumption of Komatsu D85ex bulldozer varied between 18-20 l/h.

In this study, the average zone width of the constructed sample road was $11.32 \mathrm{~m}$. The amount of forest area impacted along the road was 1.78 ha. A study conducted in the Antalya region reported that a road construction operation in the same region resulted in a zone width of $12.18 \mathrm{~m}$ (Wood and Armitage, 1997). Another study conducted by Ozturk (Ozturk, et al., 2010) — in which a bulldozer was used — in the Bolu region of Turkey indicated that the average zone width of the construction was 
$7.27 \mathrm{~m}$, and the ground type was soil. Ozturk also reported a construction zone width of $7.47 \mathrm{~m}$ on loose rock in the Eskişehir region of Turkey (Ozturk, et al., 2009).

Table 4. Productivity of bulldozer at different excavated materials

\begin{tabular}{c|c|c|c|c}
\hline $\begin{array}{c}\text { Cross section } \\
\text { number }\end{array}$ & $\begin{array}{c}\text { Excavated materials } \\
\text { ground type }\end{array}$ & $\begin{array}{c}\text { Average slope } \\
(\mathbf{\%})\end{array}$ & $\begin{array}{c}\text { Distance of between } \\
\text { cross sections }(\mathbf{m})\end{array}$ & $\begin{array}{c}\text { Productivity of } \\
\text { bulldozer }\left(\mathbf{m}^{\mathbf{3}} \mathbf{h r}\right)\end{array}$ \\
\hline 1 & Soil & 55 & 25 & 221.41 \\
2 & Loose rock & 66 & 25 & 125.00 \\
3 & Soft rock & 63 & 30 & 86.50 \\
\hline
\end{tabular}

There are two types of environmental damages caused by forest road constructions. These are damages to trees and damages to stream beds. The tree damages include bending and wounding of trees. The damages to stream beds include the filling of stream beds with excavated materials. In this study, in the $25-80 \%$ ground slopes, $26.3 \%$ of the trees below the forest road construction zone were bent, and $6.1 \%$ of the trees were wounded. In a similar study conducted by Tunay (Tunay and Melemez, 2004) in Antalya, 55\% of trees under the forest road construction zone in a terrain with a ground slope of 51\% were damaged. In a similar region, Ozturk (Ozturk, et al., 2010) reported that the types of damages that were identified on trees included bending, crushing and wounding in a karstic region. The rate of total damage including all three types was $23 \%$ in the $46-90 \%$ ground slope. Another study conducted by Caliskan in the Trabzon region of Turkey revealed that $44 \%$ of trees were damaged in soil, loose rock and rock areas of a terrain that had a ground slope of 59\% (Caliskan, 2013). Damage types in those areas included bending, crushing and wounding. Although the area in this study was a sloping area, the number of trees that were damaged was less than those that were observed in the other studies. The reason might be that the types of ground were mostly soil and loose rock. The soil load usually bends trees. The rate of wounding observed on the trees was less. In this study, dumping the excavated materials on the stream bed was a more serious problem for the environment. It appears, the risk of erosion will increase in this road area in the consequent years.

In this study, the cut-slope rates ranged from 3/1 to 5/1, and the fill-slope rate was $2 / 3$. Kramer indicated that a cut-slope rate of $3 / 1$ is the most appropriate rate especially for steep terrains (Kramer, 2001).

\section{Conclusion}

In this study, constructing a road using a bulldozer were evaluated in soil and loose rock areas by considering economic and environmental requirements. The following are recommended:

- Bulldozers should be used in forested areas with less than $45 \%$ ground slope. Environmental damage is increased in areas where slope is higher.

- A buffer zone should be maintained between a forest road and a stream. The buffer zone protects the stream bed from excavated materials.

- Damaged trees should be removed from sensitive areas where bark beetles are abundant. Especially the wounded trees will increase the number of bark beetles. This situation is very dangerous for sensitive forest areas. 
- Cut-slope rates should be $3 / 1$ or $5 / 1$ on mountainous areas. Lower rates such as $1 / 1$ or $2 / 1$ will increase construction zone widths of forest roads.

- Bulldozer operators should be well trained to improve the efficiency of construction activities, which affect economical and environmental aspects.

Acknowledgements. In this study supported by I. U. Scientific Research Projects, Project Number: BEK2017-25911. The fieldwork of this publication would like to thank for help to Hatice Muslu.

\section{REFERENCES}

[1] Acar, H. H., Eker, M. (2003): The use of excavators in forest road construction and their environmental benefits. - Journal of South-West Anatolia Forest Reserarch Institute 5: 98-128.

[2] Akgul, M. (2012): Determination of Buffer Zone Criteria for Production Forest. Unpublished Doctoral Dissertation, Institute of Sciences, Istanbul University, Istanbul.

[3] Anonymous (2015): Komatsu D85ex Buldozer Technical Catalog. - Komatsu Ltd, Tokyo.

[4] Çalışkan, E. (2013): Environmental impacts of forest road construction on mountainous terrain. - Iranian Journal of Environmental Health Science \& Engineering 10(1): 23.

[5] Demir, M., Hasdemir, M. (2005): Functional planning criterion of forest road network systems according to recent forestry development and suggestion in Turkey. - American Journal Environmental Science 1(1): 22-28.

[6] Edwards, R. M. (2011): Colorado Forest Road Field Handbook. - Colorado State Forest Service, Colorado, USA.

[7] Hernández-Díaz, C., Soto-Cervantes, J., Corral-Rivas, J., Montiel-Antuna, E., Alvarado, R., Goche-Télles, R. (2015): Impacts of forest roads on soil in a timber harvesting area in northwestern Mexico (a case study). - Croatian Journal of Forest Engineering: Journal for Theory and Application of Forestry Engineering 36(2): 259-267.

[8] Kramer, B. W. (2001): Forest Road Contracting, Construction, and Maintenance for Small Forest Woodland Owners. - Forest Research Laboratory, College of Forestry, Oregon State University, Corvallis, OR.

[9] Krč, J., Beguš, J. (2013): Planning forest opening with forest roads. - Croatian Journal of Forest Engineering: Journal for Theory and Application of Forestry Engineering 34(2): 217-228.

[10] Ozturk, T., Inan, M., Akay, A. E. (2010): Analysis of tree damage caused by excavated materials at forest road construction in karst region. - Croatian Journal of Forest Engineering: Journal for Theory and Application of Forestry Engineering 31(1): 57-64.

[11] Ozturk, T., Inan, M., Akgul, M. (2009): Environmental damages of forest road construction by bulldozer on steep terrain. - African Journal of Biotechnology 8(18): 4547-4552.

[12] Ryan, T., Phillips, H., Ramsay, J., Dempsey, J. (2004): Forest Road Manual: Guidelines for the Design, Construction and Management of Forest Roads. - COFORD, National Council for Forest Research and Development, Dublin.

[13] Tehrani, B. F., Majnounian, B., Abdi, E., Zahedi Amiri, G. (2015): Impacts of forest road on plant species diversity in a Hyrcanian forest, Iran. - Croatian Journal of Forest Engineering: Journal for Theory and Application of Forestry Engineering 36(1): 63-71.

[14] Tunay, M., Melemez, K. (2004): The assessment of environmentally sensitive forest road construction technique in difficult terrain conditions. - ITUJ Engineering 3(2-3-4-5): 310 . 
[15] Wenger, S. (1999): A review of the scientific literature on riparian buffer width, extent and vegetation. - Office of Public Service \& Outreach Institute of Ecology University of Georgia, Athens, Georgia.

[16] Wood, P. J., Armitage, P. D. (1997): Biological effects of fine sediment in the lotic environment. - Environmental Management 21(2): 203-217. 